\title{
Giới thiệu bộ công cụ đo năng lụ̣c đổi mới sáng tạo của doanh nghiệp: i2Metrix - Cổng thông tin khoa học và công nghệ thành phố Hải Phòng
}

Đây là chủ đề hội thảo do Sở KH\&CN vừa tổ chức. Hội thảo có sự tham dự của đại diện lãnh đạo Sở KH\&CN, các phòng, đơn vị thuộc Sở, đại diện Hội Doanh nghiệp Hàng Việt Nam chất lượng cao cùng đông đảo đại diện các doanh nghiệp trên địa bàn thành phố.

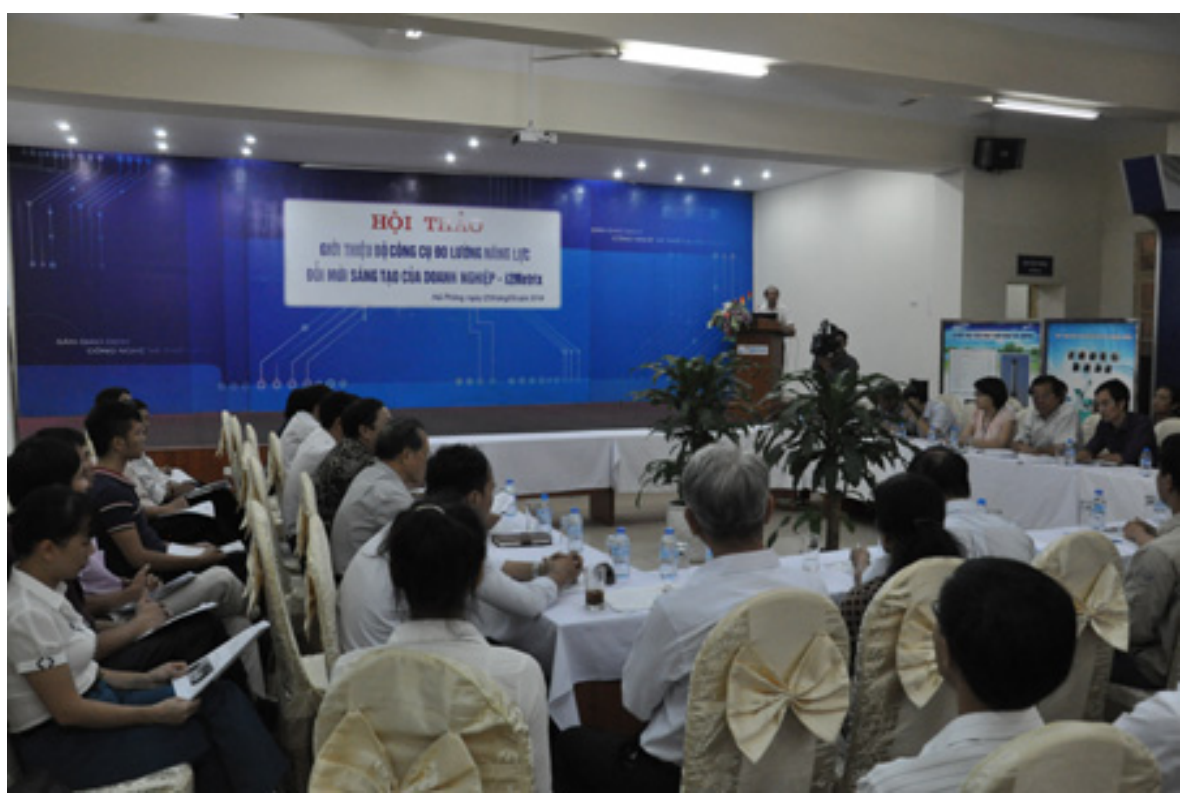

Hội thảo giới thiệu đến các đại biểu bộ công cụ đo lường năng lực đổi mới -sáng tạo của doanh nghiệp: i2Metrix. Đây là bộ chỉ số do Trung tâm Kinh doanh và Hỗ trợ doanh nghiệp (BSA) và Công ty Nghiên cứu kinh tế và tư vấn kinh doanh Dan Houtte, Vuong \& Partners Ltd (DHVP) cùng phát triển. i2Metrix giúp đo lường được quy mô nguồn lực sáng tạo, hiệu suất sử dụng và gợi ý giải pháp gia tăng hiệu quả khai thác nguồn lực này.

Với những người làm chính sách và nghiên cứu, bộ dữ liệu i2Metrix cung cấp bằng chứng thực nghiệm và chỉ rõ những nội dung cần ưu tiên về nguồn lực, chính sách và giải pháp trong thúc đẩy, hỗ trợ đổi mới - sáng tạo. Đặc biệt, i2Metrix không chỉ ứng dụng được cho các doanh nghiệp sản xuất lớn, mà ngay cả những cơ sở nhỏ, đơn vị kinh doanh đặc sản làng nghề cũng hoàn toàn có thể áp dụng các tiêu chí của bộ đo này để đánh giá năng lực đổi mới sáng tạo của mình.

i2Metrix đã thu hút sự quan tâm của đông đảo đại biểu là đại diện các doanh nghiệp về việc đánh giá năng lực đổi mới - sáng tạo theo thang điểm, việc ứng dụng trong các doanh nghiệp nhỏ, định hướng bước đi của doanh nghiệp trong đổi mới - sáng tạo...

\section{Hà Anh}


